\title{
Pre-treatment with ulipristal acetate before ICSI procedure: a case report
}

\section{Zastosowanie octanu uliprystalu przed procedurą ICSI: opis przypadku}

\author{
Artur Wdowiak \\ Laboratory of Diagnostic Procedures, Faculty of Nursing and Health Sciences, Medical University of Lublin; \\ Head of Laboratory: Artur Wdowiak MD, PhD
}

Przegląd Menopauzalny 2013; 6: 496-500

\section{Summary}

Epidemiologic data indicate that infertility is a common global problem being diagnosed in approximately one sixth of all couples. One of the reasons responsible for the inability to conceive is the presence of uterine fibroids. Many reports published recently have emphasized the high efficiency of ulipristal acetate in the treatment of uterine fibroids. In June 2012, a 35-year-old woman reported to the Non-Public Health Care Unit "Ovum Reproduction and Andrology" in Lublin for continued treatment of infertility.

However, ultrasound performed on the day of the visit at Ovum showed two intramural uterine fibroids: one of them, size $2.26 \mathrm{~cm} \times 2.53 \mathrm{~cm}$, was located in the front uterine wall touching the endometrium and the other one with a diameter of $1.2 \mathrm{~cm}$ was located in the posterior uterine wall, not compressing the endometrium. Taking all of this into consideration along with the treatment conducted so far, the couple has been qualified for an ICSI (intracytoplasmic sperm injection) procedure. Due to the presence of the fibroid in the front wall of the uterus, which might have adversely affected embryo implantation in the previous IVF procedures, an attempt was made to reduce the fibroid volume with 3-month treatment with Esmya $5 \mathrm{mg} 1 \times 1$ given for 84 days. Ultrasound performed after discontinuation of Esmya treatment showed normal size of the uterus with smooth contours and the previously detected intramural fibroid located in the posterior wall, was found to have a diameter of $1.08 \mathrm{~cm}$, illustrating a reduction from pre-treatment size. The fibroid located in the front wall of the uterus previously detected by ultrasound was no longer visible. The patient underwent ICSI treatment. The risk of multiple pregnancies was reduced by an appropriate selection of a single blastocyst for transfer. Pregnancy was achieved and further ultrasound confirmed normal anatomical structure of the fetus and the absence of other fibroids.

Key words: fibroid, infertility, ulipristal acetate, ICSI.

\section{Streszczenie}

Dane epidemiologiczne wskazują, że niepłodność jest powszechnym problemem w skali światowej, bowiem dotyczy jednej szóstej wszystkich par. Jedną z przyczyn niemożności zajścia w ciążę jest mięśniakowatość macicy. Liczne publikacje z ostatnich lat podkreślają wysoką skuteczność octanu uliprystalu w terapii mięśniaków macicy. Pacjentka, lat 35, zgłosiła się w czerwcu 2012 r. w celu kontynuacji leczenia niepłodności do ośrodka Ovum. Na podstawie badania ultrasonograficznego (USG) przeprowadzonego w dniu zgłoszenia się pacjentki, uwidoczniono obecność dwóch mięśniaków macicy zlokalizowanych śródściennie: w przedniej ścianie macicy mięśniak o wymiarach $2,26 \mathrm{~cm} \times 2,53 \mathrm{~cm}$ w styczności z endometrium oraz $w$ tylnej ścianie macicy - średnica $1,2 \mathrm{~cm}$ bez ucisku na endometrium. Ze względu na dotychczasowy przebieg leczenia parę zakwalifikowano do procedury mikroiniekcji plemnika do komórki jajowej (intracytoplasmic sperm injection - ICSI). Przed programem podjęto próbę redukcji objętości mięśniaka, stosując trzymiesięczną terapię preparatem Esmya $5 \mathrm{mg}$ $1 \times 1$ przez 84 dni. Na podstawie badania USG przeprowadzonego po odstawieniu preparatu Esmya, stwierdzono, że macica jest prawidłowej wielkości o gładkim obrysie z mięśniakiem śródściennym w ścianie tylnej o średnicy $1,08 \mathrm{~cm}$, mięśniaka w ścianie przedniej nie uwidoczniono. Dało to podstawę do przeprowadzenia procedury ICSI u pacjentki. Transferowano jedną blastocystę w celu uniknięcia ciąży wielopłodowej. Uzyskano ciążę, a kolejne badania USG potwierdzity jej prawidłowy rozwój oraz niepojawienie się innych mięśniaków.

Słowa kluczowe: mięśniak, niepłodność, octan uliprystalu, ICSI. 


\section{Introduction}

Infertility which affects many couples has been given a status of a social disease by the World Health Organization. Epidemiologic data indicate that infertility is a common global problem being diagnosed in one sixth of all couples. In Poland, infertility affects approx. $19 \%$ of couples (approx. 1 million couples), including $4 \%$ of people with infertility and $15 \%$ of people with restricted fertility.

One of the reasons responsible for inability to conceive is the presence of uterine fibroids. The effect of uterine fibroids on fertility increases as their location gets closer to the uterine cavity. Intramural fibroids modulating endometrium and submucosal fibroids are the most critical for successful conception [1]. They may be responsible for inability to conceive and miscarriage [2]. While hysteroscopic removal of submucosal fibroids is not an unfavorable prognostic factor of infertility [3], surgical removal of intramural fibroids may contribute to disrupting uterine continuity in the perinatal period. Laparotomy may also result in the development of adhesions in the abdominal cavity, which may be responsible for disturbances in follicle rupture or fallopian tube obstruction that may potentially reduce female fertility. Surgery within the uterine cavity may result in adhesions in endometrium and adversely affect the ability to get pregnant.

On the other hand, embolization may contribute to decreasing the ovarian reserve and thus reducing female fertility [4].

The position of the Polish Society of Reproductive Medicine, Society for Reproductive Biology, the Fertility and Sterility Section of the Polish Gynecological Society and Reproductive Medicine Commission of the Committee on Biology of Animal Reproduction of the Polish Academy of Sciences presented in January 2009 on ART (Assisted Reproduction Technology) treatment of infertility and its consequences emphasizes that classical methods of surgical treatment improve the chances of pregnancy only to a slight extent.

Pharmacotherapy with ulipristal acetate (Esmya), aromatase inhibitors, antiprogestin (CDB-2914) or $\mathrm{GnRH}$ analogues may be an alternative to surgery or embolization used in the treatment of uterine fibroids [5-7].

Many reports published recently have emphasized high efficiency of ulipristal acetate in the treatment of uterine fibroids [8-10].

\section{Case report}

In June 2012, a 35-year-old woman reported to the Non-Public Health Care Unit 'Ovum Reproduction and Andrology' in Lublin for continued treatment of infertility. The patient's medical records indicated that she has been trying to get pregnant for 6 years. So far, she has had 4 inseminations and 2 intracytoplasmic sperm injection (ICSI) procedures. Hormone testing indicated normal ovarian reserve, normal course of ovulation and 28-day cycles. The patient complained about painful and heavy menses. Sonographic examination performed in 2008 showed that the shape of uterus was normal and fallopian tubes were patent. However, ultrasound (Aloka ProSound 3500 SX) performed on the day of the visit at Ovum (day 6 of the menstrual cycle) showed two intramural uterine fibroids: one of them, size $2.26 \mathrm{~cm} \times 2.53 \mathrm{~cm}$ was located in the front uterine wall touching the endometrium and the other one with a diameter of $1.2 \mathrm{~cm}$ was located in the posterior uterine wall, not compressing endometrium. The appendages were free of pathological changes and their size was normal (Fig. 1). The analysis of the parameters of husband's sperm collected between 2007 and 2012 showed sperm density of 1 to $6 \mathrm{mln} / \mathrm{ml}$, progressive movement motility of 10 to $35 \%$, the percentage of pathological spermatozoa above the normal range according to normal ranges defined by WHO before 2010 and later, and ejaculation volume of 1 to $2.5 \mathrm{ml}$. Sonographic assessment of the man's testes did not reveal any anomalies. Hormonal testing of the husband showed slightly elevated FSH (follicle-stimulating hormone) and LH (luteinizing hormone) serum levels which made gonadotropin therapy inadvisable. At other centers, the husband has been treated with vitamin preparations, polfilin and anti-inflammatory agents without signs of improvement in sperm parameters. We have investigated the percentage of spermatozoa with DNA fragmentation finding that the proportion of chromatin damage was normal. The interview with the man did not provide any information about chronic diseases. Because of this and taking into consideration the treatment conducted so far, the couple has been qualified for ICSI procedure. Because of the presence of the fibroid in the front wall of the uterus which might have

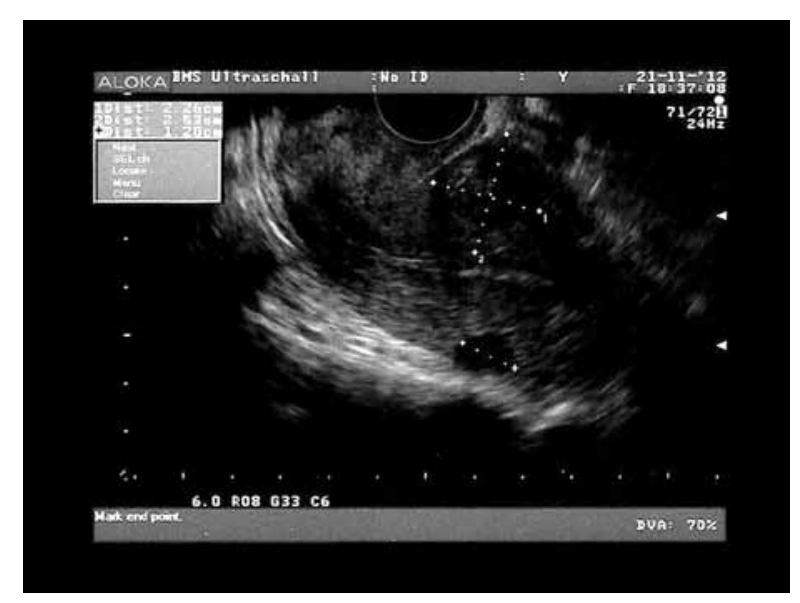

Fig. 1. Ultrasound image of the uterus before treatment 
adversely affected embryo implantation in the previous IVF (in vitro fertilisation) procedures, an attempt has been made to reduce the fibroid volume with 3-month treatment with Esmya $5 \mathrm{mg} 1 \times 1$ given for 84 days. The patient started the therapy on 21 Nov 2012, on day 3 of her menstrual cycle. The patient had no complaints or side effects during treatment with Esmya. Menstrual bleeding did not occur while the patient was taking Esmya tablets. The first menstrual bleeding after treatment discontinuation was on 1 March 2013, it was rather scanty and painless. Ultrasound performed after discontinuation of Esmya treatment showed normal size of the uterus with smooth contours and an intramural fibroid located in the posterior wall; fibroid diameter was $1.08 \mathrm{~cm}$. The fibroid located in the front wall of the uterus detected by ultrasound on $21 \mathrm{Nov}$ 2012 has not been visualized, the appendages had normal size and were free of pathological changes (Fig. 2). Ultrasound examination showed normal structure of the uterus, which warranted ICSI procedure in our patient. The stimulation for IVF was preceded by tests excluding infectious diseases, blood cell count, clotting parameters and electrocardiogram (ECG). No contraindications to IVF were found in these investigations.

The ovarian stimulation was carried out by the administration of luteal gonadotropin-releasing hormone analogue (GnRHa) (Diphereline 0.1: Ipsen Pharma) followed by recombinant 150 j.FSH (Gonal-F: Merck-Serono) from cycle day 3. Vaginal ultrasound-guided aspiration of oocyte-cumulus complexes was performed $36 \mathrm{~h}$ after recombinant human chorionic gonadotropin administration ( $r$-hCG) (Ovitrelle: Merc-Serono).

Stimulation for IVF day 11 resulted in 12 vesicles with a diameter of 18 to $21 \mathrm{~mm}, 12.5 \mathrm{~mm}$ endometrium; the increase in fibroid size or the occurrence of new fibroids were not observed and the estradiol level was 2470 . Eleven egg cells have been sampled during puncture.

Oocyte denudation and ICSI were performed $3 \mathrm{~h}$ after retrieval and the in vitro culture was carried out

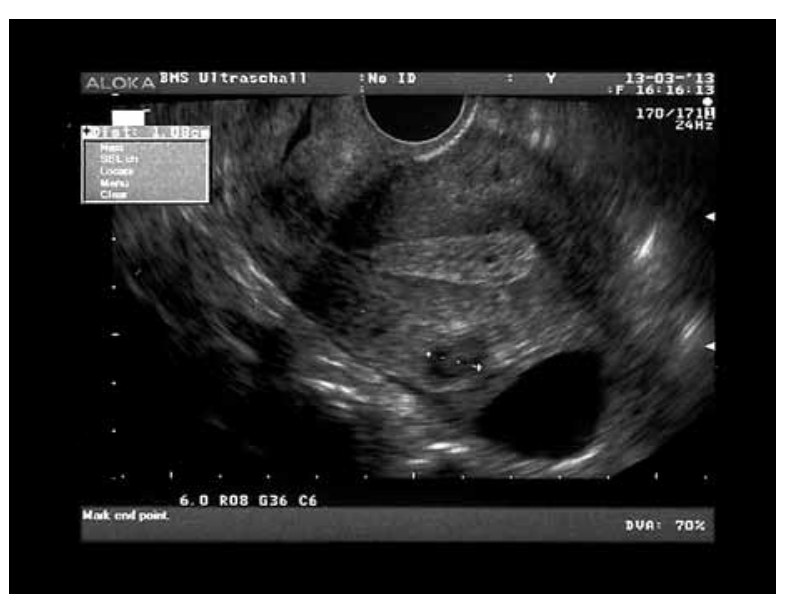

Fig. 2. Ultrasound image of the uterus after treatment in $25 \mu \mathrm{l}$ of Cleavage medium (COOK, Sydney IVF, Australia) under mineral oil until day 2 (2-5 cells stage) in automated incubators with $5 \% \mathrm{CO}_{2}$, at $37^{\circ} \mathrm{C}$ fitted with time-lapse image acquisition (Primo Vision EVO Microscope, Cryo-Innovation, Hungary). Fifty hours from ICSI the in vitro culture media were changed to Blastocyst medium (COOK, Sydney IVF, Australia). During incubation images were generated each $10 \mathrm{~min}$ and recorded.

A noninvasive test combining time-lapse image analysis with the cell-tracking software, Primo Vision Evo Microscope (Cryo-Innovation), was used to measure early embryo development and generate usable blastocyst.

The time to was defined as the time of ICSI. The tF was defined as the time of the first frame in which both pronuclei could be observed. The time tC was the frame with the last observation of both pronuclei. From this time, the nucleolus precursor bodies decreased in size and subsequently disappeared, followed by pronuclei membrane flattening. The successive frame corresponded to one cell stage and it was annotated as t1. The t2, t3, t4, t5, t6, t7, t8 and t9 were defined as the times for the corresponding number of cells ( $t 2$ for 2 cells, $\mathrm{t} 3$ for 3 cells, etc.). The times were annotated at the first frame in which the cells (blastomeres) were seen as separated by individual membranes. The time tM was defined as the first frame in which the embryos were compacting into the morula stage. The tB time was defined as the frame in which a crescent-shaped area began to emerge from the morula. The successive frame was the time tEB of expanded blastocyst, consistent with the increase of the overall volume of the embryo and expansion of the blastocoele cavity.

ICSI resulted in 10 fertilizations on the first day of embryo culture. During embryo culture up to blastocyst stage, the development of 2 embryos has stopped at 2-cell stage and 5-cell stage.

Table I shows the times of the development of $8 \mathrm{em}$ bryos which reached the blastocyst stage during culture.

Embryo culture showed that the times of the development of a given blastocyst up to the transfer in the patient were similar to those described by other authors.

As our patient had the history of fibroids, a decision was made to use one blastocyst in order to avoid plural pregnancy and consequently, a higher risk of premature birth. Seven blastocysts have been frozen. Fourteen days after puncture, the HCG level was assessed (result: 150) confirming pregnancy. Three weeks later, an ultrasound examination was performed showing single gestational vesicle in the uterine cavity, with a single embryo with a detectable heart rate, normal size of yolk sac (CRL and GS values were consistent with the date of the last menstrual bleeding) and an intramural fibroid with a diameter of $1.1 \mathrm{~cm}$ located in the posterior uterine wall. Ultrasound examination performed in week 13 of pregnancy revealed normal anatomical structures of 
Table I. Embryo kinetic data. All data are expressed in hours and fractions on an hour

\begin{tabular}{lcccccccccccccc}
\hline No. & tF & tC & t1 & t2 & t3 & t4 & t5 & t6 & t7 & t8 & t9 & tM & tB & $\begin{array}{c}\text { Achieved } \\
\text { pregnancy }\end{array}$ \\
\hline 1. & 10 & 17 & 18.8 & 21.4 & 28.1 & 33.5 & 37.5 & 46.7 & 72 & 49.3 & 57.3 & 101.3 & 103 & 1 \\
\hline 2. & 15 & 17.7 & 19 & 22.2 & 28.1 & 34.1 & 53.2 & 53.6 & 47.7 & 63.4 & 59.7 & 89.7 & 103.1 & \\
\hline 3. & 14.7 & 18.8 & 19.2 & 23.2 & 29 & 34.3 & 52.3 & 52.3 & 60.1 & 68.4 & 93.5 & 90.4 & 103.7 \\
\hline 4. & 4.9 & 23.1 & 19.7 & 23.2 & 29 & 34.3 & 54.3 & 51.1 & 49.9 & 48.5 & 72.4 & 87.5 & 103.8 \\
\hline 5. & 4.8 & 19.3 & 19.8 & 21.8 & 30.1 & 34.2 & 37.8 & 55.5 & 47.8 & 56.4 & 76.6 & 86 & 104 & \\
\hline 6. & 9.1 & 21.1 & 20.1 & 22.4 & 29.3 & 35.3 & 37.9 & 47.7 & 46.9 & 55.4 & 78.9 & 78.9 & 103.2 & \\
\hline 7. & 9.2 & 19.1 & 20.4 & 23.3 & 28.2 & 33.5 & 38 & 48.9 & 51.6 & 61 & 56.7 & 103 & 104.3 & \\
\hline 8. & 8.6 & 29.3 & 21.1 & 22.1 & 28.3 & 34.7 & 38.6 & 47.7 & 52.8 & 60.9 & 67.3 & 102.4 & 104.1 & \\
\hline
\end{tabular}

the fetus, nuchal translucency - $1.4 \mathrm{~mm}$, visible nasal bone and biometry consistent with the date of the last menstrual bleeding. Another ultrasound examination performed in week 16 of pregnancy confirmed normal anatomical structure of the fetus and the absence of fibroid growth in the posterior uterine wall as well as the absence of other fibroids.

\section{Discussion}

Table II compares the times of embryo development measured at our site with the results obtained by other authors. Our results were comparable with those given in the literature $[11,18]$. It makes us presume that Esmya does not have adverse effect on the quality of egg cell produced. Initial assessment of the anatomy of the fetus developing as a result of ICSI procedure did not reveal any anomalies, which is consistent with literature data and suggests safety of the treatment applied [1]. It is beyond any doubt that the use of Esmya in the treatment of infertility requires further studies.

\section{Conclusions}

The use of Esmya does not affect the course of ovarian stimulation or the rate of embryo development in the ICSI procedure.

Esmya is the best alternative to surgery and embolization of uterine fibroids in patients planning to become pregnant.

Table II. Comparison of our data and data in the literature. All data are expressed in hour and fraction of an hour

\begin{tabular}{|c|c|c|c|c|c|c|c|c|c|}
\hline \multirow{2}{*}{$\begin{array}{l}\text { Type } \\
\text { of } \\
\text { data }\end{array}$} & \multirow{2}{*}{$\begin{array}{c}\text { Our data } \\
\text { Mean/Median }\end{array}$} & \multirow{2}{*}{$\begin{array}{c}\text { Chamayou } \\
\text { et al. } \\
\text { Mean/Median }\end{array}$} & \multirow{2}{*}{$\begin{array}{l}\text { Azza- } \\
\text { rello et } \\
\text { al. [11] } \\
\text { Inferior } \\
\text { Limit }\end{array}$} & \multirow{2}{*}{\multicolumn{2}{|c|}{$\begin{array}{c}\text { Ciray et al. [13] } \\
\text { Mean }\end{array}$}} & \multirow{2}{*}{$\begin{array}{c}\text { Mesegu- } \\
\text { er et al. } \\
{[18]} \\
\text { Mean }\end{array}$} & \multicolumn{2}{|c|}{ Dal Canto et al. [16] } & \multirow{2}{*}{$\begin{array}{l}\text { Kirkegaard } \\
\text { et al. [17] } \\
\text { Median }\end{array}$} \\
\hline & & & & & & & Mean & Mean & \\
\hline $\begin{array}{l}\text { no. of } \\
\text { emb. }\end{array}$ & 8 & 72 & 37 & 9 & 9 & 61 & 93 & 19 & 53 \\
\hline t1 & $19.76(18.8-29.3)$ & $24.1(18.4-30.9)$ & 20.57 & & & & & & \\
\hline t2 & $22.45(21.4-23.3)$ & $26.9(21.4-34.8)$ & & $24.7 \pm 3.6$ & $27.9 \pm 3.4$ & $25.6 \pm 2.2$ & $27.9 \pm 4.1$ & & $26.1(25.2-26.9)$ \\
\hline t3 & $28.76(28.1-30.1)$ & $38.3(27.8-47.8)$ & & $35.7 \pm 5.1$ & $40.1 \pm 4.1$ & $37.4 \pm 2.8$ & $27.9 \pm 4.6$ & & 35.7 (34.3-37.3) \\
\hline t4 & $34.23(33.5-35.3)$ & $40.3(33.1-57.2)$ & & $36.6 \pm 4.3$ & $41.4 \pm 4.5$ & $38.2 \pm 3.0$ & $40.2 \pm 5.8$ & & $37.6(35.9-39.3)$ \\
\hline t5 & $43.7(37.5-54.3)$ & $53.0(37.5-67.0)$ & & $47.4 \pm 7.9$ & $53.9 \pm 6.0$ & $52.3 \pm 4.2$ & $50.2 \pm 6.7$ & $49.4 \pm 4.9$ & $49.6(47.3-52.0)$ \\
\hline t6 & $50.43(46.7-55.5)$ & $54.3(46.1-73.5)$ & & & & & $53.9 \pm 7.6$ & & $52.4(50.1-54.9)$ \\
\hline t7 & $53.6(46.9-72)$ & $57.4(46.1-73.5)$ & & & & & $58.8 \pm 10.4$ & & $58.0(55.5-60.5)$ \\
\hline t8 & $57.91(48.5-68.4)$ & $61.0(46.4-97.8)$ & & & & & $65.2 \pm 13$ & $54.9 \pm 5.2$ & $60.5(57.8-63.4)$ \\
\hline $\mathrm{CO}_{2} \%$ & 5 & 5 & 5.5 & ( & 6 & 5 & & & 6 \\
\hline $\mathrm{O}_{2} \%$ & 20 & 5 & 5 & & 5 & 20 & & & 20 \\
\hline $\begin{array}{l}\text { me- } \\
\text { dium }\end{array}$ & COOK & SAGE & COOK & Irvine (sir & gle) (Seq) & SAGE & & & COOK \\
\hline
\end{tabular}




\section{References}

1. Guo XC, Segars JH. The impact and management of fibroids for fertility: an evidence-based approach. Obstet Gynecol Clin North Am 2012; 39: 521-33.

2. Richards PA, Richards PD, Tiltman AJ. The ultrastructure of fibromyomatous myometrium and its relationship to infertility. Hum Reprod Update 1998; 4: 520-5.

3. Pakrashi T, Ressler IB, Sroga JM, et al. Hysteroscopic enucleation of type Il submucosal uterine leiomyomas using a TRUCLEAR hysteroscopic morcellator: case report and review of the literature. J Laparoendosc Adv Surg Tech A 2013; 23: 378-82.

4. Chang KM, Chen MJ, Lee MH, et al. Fertility and pregnancy outcomes after uterine artery occlusion with or without myomectomy. Taiwan J Obstet Gynecol 2012; 51: 331-5.

5. Hoellen F, Griesinger G, Bohlmann MK.Therapeutic drugs in the treatment of symptomatic uterine fibroids. Expert Opin Pharmacother 2013; 14: 2079-85.

6. Islam MS, Protic O, Giannubilo SR, et al. Uterine leiomyoma: available medical treatments and new possible therapeutic options. J Clin Endo crinol Metab 2013; 98: 921-34.

7. Lewis El, Chason RJ, DeCherney AH, Armstrong A, Elkas J, Venkatesan AM. Novel hormone treatment of benign metastasizing leiomyoma: an analysis of five cases and literature review. Fertil Steril 2013; 99: 2017-24.

8. Ogliari KS, Mohallem SV, Barrozo P, Viscomi F. A uterine cavity-myoma communication after uterine artery embolization: two case reports. Fertil Steril 2005; 83: 220-2.

9. Driák D, Sehnal B, Svandová I. Selective progesterone receptor modulators and their therapeutical use. Ceska Gynekol 2013; 78: 175-81.
10. Szamatowicz M, Kotarski J. Selective progesterone receptor modulator (ulipristal acetate) - a new option in the pharmacological treatment of uterine fibroids in women. Ginekol Pol 2013; 84: 219-22.

11. Azzarello A, Hoest T, Mikkelsen AL. The impact of pronuclei morphology and dynamicity on live birth outcome after time-lapse culture. Hum Reprod 2012; 27: 2649-57.

12. Chamayou S, Patrizio P, Storaci G, et al. The use of morphokinetic parameters to select all embryos with full capacity to implant. J Assist Reprod Genet 2013; 30: 703-10.

13. Ciray HN, Aksay T, Goktas C, et al. Time-lapse evaluation of human embryo development in single versus sequential culture media - a sibling oocyte study. J Assist Reprod Genet 2012; 29: 891-900.

14. Conaghan J, Chen AA, Willman SP, et al. Improving embryo selection using a computer-automated time-lapse image analysis test plus day 3 morphology: results from a prospective multicenter trial. Fertil Steril 2013; 100: 412-9.e5.

15. Cruz M, Gadea B, Garrido N, et al. Embryo quality, blastocyst and ongoing pregnancy rates in oocyte donation patients whose embryos were monitored by time-lapse imaging. J Assist Reprod Genet 2011; 28: 569-73.

16. Dal Canto M, Coticchio G, Mignini Renzini M, et al. Cleavage kinetic analysis of human embryos predicts development to blastocyst and implantation. Reprod Biomed Online 2012; 25: 474-80.

17. Kirkegaard K, Kesmodel US, Hindkjćr JJ, Ingerslev HJ. Time-lapse parameters as predictors of blastocyst development and pregnancy outcome in embryos from good prognosis patients: a prospective cohort study. Hum Reprod 2013; 28: 2643-51.

18. Meseguer M, Herrero J, Tejera A, Hilligsøe KM, Ramsing NB, Remohí J. The use of morphokinetics as a predictor of embryo implantation. Hum Reprod 2011; 26: 2658-71. 